\title{
A comprehensive review of renewable energy production from biomass-derived bio-oil
}

\author{
Monika Sharma ${ }^{1}$, Joginder Singh ${ }^{1}$, ChinNAPPAN BASKAR ${ }^{2}$, AJAY KUMAR ${ }^{1 *}$ \\ ${ }^{1}$ School of Bioengineering and Biosciences, Lovely Professional University, Phagwara, Punjab, India \\ ${ }^{2}$ THDC Institute of Hydropower Engineering and Technology, Tehri Uttarakhand Technical University, Dehradun, Uttarakhand, India
}

\begin{abstract}
Renewable energy production has attracted great attention due to public concerns about the depletion of fossil fuels and the growing emphasis on zero carbon emissions. Two main drivers have pushed renewable energy production to the top of the global agenda: climate change and energy security. Biomass is considered to be the only sustainable source of organic carbon on earth and the perfect equivalent to petroleum for the production of bioenergy, biofuels and fine chemicals with net zero carbon emission in a biorefinery. This review focuses on the potential of producing energy from different biomasses and describes technologies such as direct combustion, microwave technology, hydrothermal liquefaction, and fast pyrolysis to convert biomass into bioenergy. Herein, innovative scalable concepts are provided to perform microwave pyrolysis on a larger scale. Current research is mainly focused on the use of catalysts to enhance the process. Various parameters affect the biomass pyrolysis process, properties, and yields of products. These generally include the biomass source, biomass pretreatment (physical, chemical, and biological), the catalyst, the reaction atmosphere, temperature, the heating rate, and the pressure and vapor residence time. The study also shows how various types of reactors affect the bio-oil yield in the presence of a catalyst.
\end{abstract}

Key words: biomass, hydrothermal liquefaction (HTL), microwave pyrolysis, bio-oil, bioenergy

\section{Introduction}

Fossil fuels play a major role in meeting the world's energy requirements. Large consumption of fossil fuels creates many environmental problems, such as increased production of greenhouse gases (GHGs), and has motivated the search for alternative renewable fuel options (Chinnappan et al., 2016). It has been recognized that the formation of fossil resources is much slower than their extraction, causing its depletion at a fast rate (Höök and Tang, 2013). Faced with this reality, countries have been developing policies to change the energy matrix to enhance the share of renewable sources (Gabrielle et al., 2014). Biomass is one of the few resources that has the potential to meet the challenges of sustainable and renewable green energy systems. Current biomass resources comprise primarily industrial waste ma- terials such as sawdust or pulp process wastes, hog fuel, forest residues, clean wood waste from landfills, and agricultural prunings, and residues from plants such as lignocellulosic materials. Research studies have aimed at obtaining energy from existing biomass that includes solid residues from agriculture like coffee husks, sugarcane bagasse, rice husks, and wheat straw (Dickerson and Soria, 2013). In many countries, agricultural wastes are burnt, leading to the emission of GHGs such as $\mathrm{CO}_{2}$, $\mathrm{NO}_{\mathrm{x}}$ and $\mathrm{SO}_{\mathrm{x}}$. Therefore, to achieve the Kyoto Protocol (an agreement under the United Nations Framework Convention on Climate Change) target of emission of GHGs, it is necessary to convert biomass into liquid fuels for direct use via biomass pyrolysis, catalytic cracking, or a gasification process (Bradley and Solutions, 2006). The conversion of biomass to liquid products

\footnotetext{
*Corresponding author: School of Bioengineering and Biosciences, Lovely Professional University, Phagwara, Punjab, India; e-mail: kumarajaybiotech@gmail.com
} 


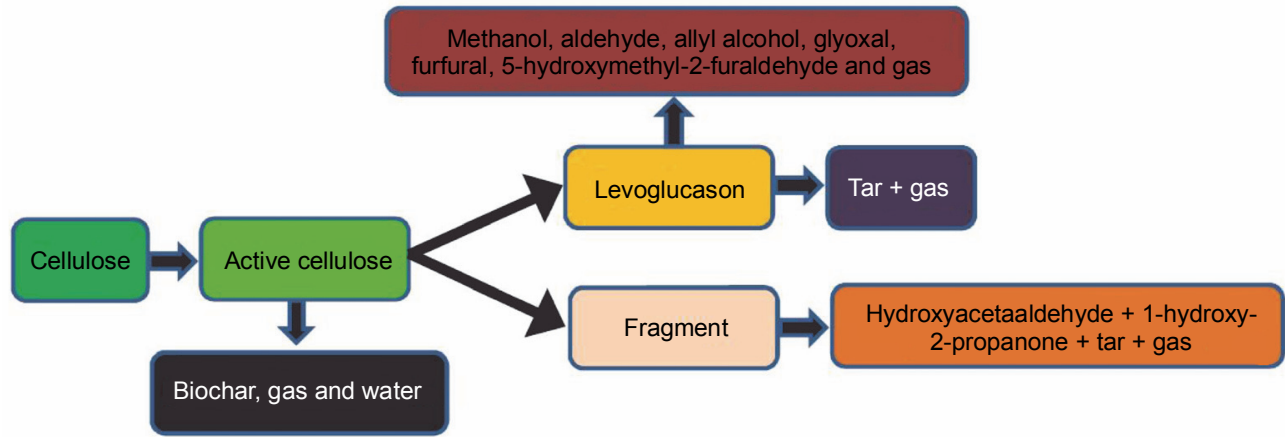

Fig. 1. Conversion of lignocellulosic biomass (Zhou et al., 2011)

begins with a process called pyrolysis. It involves thermal degradation of lignocellulosic biomass through a series of complex reactions by sweeping nitrogen gas in an oxygenless environment. The structural components of biomass are decomposed into lower molecular weight substances like biochar and bio-oil, along with gases. These products are categorized as sources of chemicals and renewable energy (Aysu, 2015). A roadmap of the conversion of lignocellulosic biomass is shown in Figure 1.

Various catalysts are used for cracking biomass to generate different products (Mamaeva et al., 2016). Lignocellulosic biomass catalysts are used in catalytic pyrolysis to produce high-grade bio-oil and chemicals. Biomass pyrolysis catalysts like zeolite (FCC, ZSM-5, and HZSM-5), and alkalis $\left(\mathrm{Na}_{2} \mathrm{CO}_{3} / \gamma-\mathrm{Al}_{2} \mathrm{O}_{3}, \mathrm{MgO}, \mathrm{K}_{2} \mathrm{CO}_{3}\right.$, and $\mathrm{Ca}(\mathrm{OH})_{2}$ ) help influence bio-oil quality (Gong et al., 2011). The catalysis process in pyrolysis involves cracking, deoxygenation, polymerization, oligomerization, alkylation, cyclization, aromatization, and isomerization. The operating parameters for batch, fixed, auger, and fluidized-bed pyrolyzers include nitrogen flow rate, biomass loading, and biomass particle size (Adhikari et al., 2014).

For the production of bio-oil, a wide range of biomass sources is available and these are divided into groups that include residues, municipal waste and virgin resources. Figure 2 shows bio-oil upgrading via cracking. A residue is a substance that remains after the process of combustion or evaporation. Wood residues include bark, leaves, and branches. Virgin resources are oil crops and forest resources (Morgan et al., 2017). Algal biomass has become the focus of attention of many researchers due to its crude bio-oil content, a fuel precursor (Wang et al., 2018a).

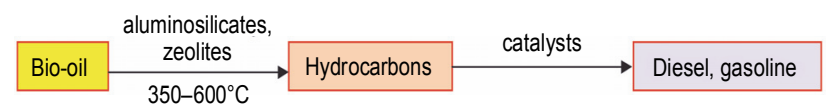

Fig. 2. Scheme of bio-oil upgrading via cracking (Bulushev and Ross, 2011)

Grierson et al. (2009) performed a study on Nannochloropsis sp. with slow pyrolysis parameters and reported that the oil yield increased from 19 to $31 \% \mathrm{w} / \mathrm{w}$ in the presence of HZSM-5 catalyst. An additional advantage of using a catalyst is the higher heating value of a liquid product (32.7 $\left.\mathrm{MJ} \mathrm{kg}^{-1}\right)$. Cellulose has a rigid structure due to the presence of strong hydrogen bonds. However, according to some literary sources, the pretreatment of cellulose is done before the liquefaction pro cess to enhance bio-oil yield (Baloch et al., 2018; Kumar and Sharma, 2017). Both hydrothermal liquefaction and ultrasonic pretreatment have been used for the production of bio-oil (Shi et al., 2013).

\section{Bio-oil}

Bio-oil is a dark brown free-flowing, organic liquid with $15-5 \%$ water content, comprising oxygenated compounds. The synonyms used for bio-oil include bio-crude oil (BCO), liquid wood, pyroligeous acid, wood distillate, wood oil, liquid smoke, pyrolysis liquid, or pyrolysis oil. It is a liquid produced by depolymerizing and fragmenting biomass content during pyrolysis (Ren et al., 2009). Chemically, bio-oil constitutes a chemical mixture of isoeugenol, furancarboxy aldehydes, pyrones, formic acid, acetic acid, water, catechols, vanillins, guaiacols, syringols, and other carboxylic acids. Other major compounds present in bio-oils are sugars, phenolics, carboxylic acids, hydroxy aldehydes, and hydroxy ketones. Ele- 
Table 1. Comparison of Bio oil and fossil oil obtained from fast pyrolysis

\begin{tabular}{|c|c|c|c|c|c|c|c|c|c|c|}
\hline \multirow[b]{2}{*}{ No. } & \multirow[b]{2}{*}{ Substrates } & \multicolumn{7}{|c|}{ Yield } & \multirow[b]{2}{*}{$\begin{array}{l}\text { Water } \\
\text { content }\end{array}$} & \multirow[b]{2}{*}{ References } \\
\hline & & $\begin{array}{c}\mathrm{C} \\
{[\%]}\end{array}$ & $\begin{array}{c}\mathrm{H} \\
{[\%]}\end{array}$ & $\begin{array}{c}\mathrm{O} \\
{[\%]}\end{array}$ & $\begin{array}{c}\mathrm{N} \\
{[\%]}\end{array}$ & $\begin{array}{c}\mathrm{S} \\
{[\%]}\end{array}$ & $\begin{array}{c}\text { Density } \\
{[\mathrm{kg} / \mathrm{l}]}\end{array}$ & $\begin{array}{c}\text { Viscosity } \\
{[\mathrm{Pa} \cdot \mathrm{s}]}\end{array}$ & & \\
\hline 1 & Wood & 56.60 & 6.20 & 37.20 & 0.10 & - & 1.30 & 0.10 & - & Mohan et al., 2006 \\
\hline 2 & Microalgae & 62.52 & 8.52 & 20.19 & 9.89 & - & 1.16 & 0.11 & 16.7 & Dote et al., 1994 \\
\hline 3 & $\begin{array}{l}\text { Autotrophic } \\
\text { C. protothecoides }\end{array}$ & 62.07 & 8.76 & 19.43 & 9.74 & - & 1.06 & 0.10 & 19.4 & Rapagna et al., 2000 \\
\hline 4 & Fossil oil & 85.00 & 11.0 & 1.0 & 0.06 & 1.0 & 0.86 & $2-1000$ & & Miao et al., 2004 \\
\hline 5 & HTL lignocellulose & 67 & 6 & 15 & 1 & - & 0.82 & $>300$ & 43536 & Hoffman, 2013 \\
\hline 6 & HTL algae (biocrude) & 77 & 10 & 6 & 4 & 0.3 & 0.95 & - & 43503 & Duan et al., 2011 \\
\hline 7 & HTL algae (aqueous) & 2.1 & 11 & 84 & 0.8 & - & 1.02 & 7.7 & - & Biller et al., 2011 \\
\hline
\end{tabular}

mental analysis, gas chromatography, and mass spectrometry are used for the determination of the quality of bio-oil and the presence of phenolic compounds (Yaman et al., 2018). Most of the studies are focused on the optimization of bio-oil yield. Further research should be carried out to improve the quality of bio-oil, such as satisfactory content of volatiles, a lower content of ash and increase in fixed carbon in bio-oil yield (Guedes et al., 2017). The most prominent algae for bio-oil production are seaweeds and multicellular green, brown, and red algae that frequently and closely bear resemblance to terrestrial plants (Duan et al., 2018). Microalgae have a superior photosynthetic efficiency with a quicker growth than lignocellulosic plants (Mohan et al., 2006). Distinctive properties of bio-oil and fossil oil from fast pyrolysis of wood and microalgae are compared in Table 1.

\section{Properties of bio-oil}

The exact chemical nature of bio-oil is largely dependent on pyrolysis variables and feedstock. Several compounds present in pyrolysis oils, like ketones or aldehydes, can react with aldol condensations that occur during handling or storage to form larger molecules in pyrolysis oil. The produced bio-oil production has 25\% water (by weight) which cannot be readily separated and high oxygen content, about $45-50 \%$. The amount of oxygen is the major reason for the variation in the behavior and properties of pyrolysis oils and hydrocarbon fuels. Bio-oil is immiscible with liquid hydrocarbons as it is hydrophilic and polar in nature. Its physical properties include water content, $\mathrm{pH}$ value, stability, viscosity, lower heating value (LHV), and higher heating value
(HHV). An oxygen bomb calorimeter is used to measure HHV. Proximate analyses, with elemental analysis, is given in Table 2, for different biomass sources. HHV and LHV of bio-oils can be calculated approximately from the following empirical correlation (Kan et al., 2016):

$$
\begin{aligned}
\mathrm{HHV}[\mathrm{MJ} / \mathrm{kg}] & =0.3491 \times \mathrm{C}+1.1783 \times \mathrm{H}+0.1005 \times \mathrm{S}- \\
& -0.1034 \times \mathrm{O}-0.0151 \times \mathrm{N}-0.0211 \times \mathrm{A}
\end{aligned}
$$

where $\mathrm{C}, \mathrm{H}, \mathrm{S}, \mathrm{O}$, and $\mathrm{N}$ are the weight percentages of carbon, hydrogen, sulfur, oxygen, and nitrogen, respectively, and $A$ is the weight percent of ash.

$$
\mathrm{LHV}[\mathrm{KJ} / \mathrm{kg}]=\mathrm{HHV}[\mathrm{KJ} / \mathrm{kg}]-218.3 \times \mathrm{H}
$$

where $\mathrm{H}$ is the weight percentage of hydrogen.

\section{Biomass conversion technology}

Biomass conversion from solid to liquid form is a nonspontaneous process. Biomass conversion technologies are classified into two categories,thermochemical, and biochemical conversion. Biochemical conversions are performed at lower temperature ranges than thermochemical conversion. Thermochemical conversion is characterized by the use of catalysts for obtaining liquid products and is classified into pyrolysis, gasification, direct conversion and liquefaction (Ross et al., 2010). Xiong et al. (2009) reported that thermal pyrolysis converts lignocellulosic biomass into bio-oils with a range of constituents such as phenolics, acids, hydrocarbons, and oxygenates. Cellulose gets decomposed to levoglucosan and fragmented into linear compounds such as acetones, alcohols, and ketones, and furfural (Hilten et al., 2009), and hemicellulose (cross-linked cellulose that primarily 
Table 2. Elemental (C, H, O, N, S) and proximate (MC, volatile, HHV, ash) analysis of biomass

\begin{tabular}{|c|c|c|c|c|c|c|c|c|c|c|c|c|c|c|}
\hline Biomass & $\mathrm{C}$ & $\mathrm{H}$ & 0 & $\mathrm{~N}$ & S & $\mathrm{H} / \mathrm{C}$ & $\mathrm{O} / \mathrm{C}$ & $\begin{array}{c}\mathrm{MC} \\
{[\mathrm{wt} \%]}\end{array}$ & $\begin{array}{l}\text { Volatile } \\
\text { [wt \%] }\end{array}$ & $\begin{array}{c}\mathrm{HHV} \\
{[\mathrm{MJ} / \mathrm{kg}]}\end{array}$ & $\begin{array}{l}\text { Ash } \\
\text { [wt\%] }\end{array}$ & $\begin{array}{l}\text { Analysis method } \\
\text { of HHV }\end{array}$ & $\begin{array}{c}\text { Tempera- } \\
\text { ture } \\
{\left[{ }^{\circ} \mathrm{C}\right]}\end{array}$ & Reference \\
\hline Wheat straw & 58.4 & 6.0 & 38.20 & 0.1 & nd & 1.46 & 0.258 & nd & 75.00 & nd & nd & calorimeter & 750 & Ren et al., 2009 \\
\hline Almond shell & 47.63 & 5.71 & 44.48 & nd & nd & 1.44 & 0.700 & 7.90 & 24.00 & nd & 1.16 & calculation & 750 & Braz et al., 2014 \\
\hline Corn & 43.04 & 6.42 & 49.27 & 1.03 & nd & 1.76 & 0.858 & 7.8 & 28.54 & nd & 8.06 & calorimeter & nd & Ren et al., 2009 \\
\hline Corn cob (fruits part) & 42.90 & 6.41 & 49.23 & 0.70 & nd & 1.79 & 0.8600 & 6.44 & nd & nd & 2.3 & oxygen bomb calorimeter & 923 & Yanik et al., 2007 \\
\hline hardwood & 55.3 & 6.6 & 51.29 & 0.4 & nd & 1.56 & 0.934 & nd & 85.58 & 19.9 & 0.6 & calorimeter & 950 & Singh et al., 2016 \\
\hline Cottonseed & 48.28 & 5.69 & 38.77 & 1.33 & nd & 1.36 & 0.588 & nd & nd & 18.3 & 5.8 & calorimeter & 700 & Ozbay et al., 2001, Demirbas, 2001 \\
\hline Pine sawdust & 44.80 & 6.56 & 48.49 & 0.05 & 0.1 & 1.08 & 0.14 & 18.76 & 80.2 & 17.13 & nd & oxygen bomb calorimeter & nd & Ronsee et al., 2013 \\
\hline Groundnut shell & 48.27 & 5.70 & 39.40 & 0.80 & nd & 1.42 & 0.612 & nd & 54.58 & nd & nd & calorimeter & nd & Perez et al., 2002 \\
\hline Hazelnut shell & 49.94 & 5.65 & 42.81 & 0.27 & nd & 1.36 & 0.643 & 5.73 & nd & 2.21 & 5.73 & calculation & 600 & Yang et al., 2009 \\
\hline Microalgae & 50.00 & 7.11 & 30.70 & 7.25 & 0.54 & 0.14 & 0.614 & 4.59 & nd & 21.10 & 7.30 & calorimeter & 450 & Ahmad et al., 2011 \\
\hline Peanut shell & 46.59 & 6.00 & 53.65 & 2.06 & nd & 1.55 & 0.703 & 7.98 & nd & 16.52 & 12.80 & calculation & 650 & Safi et al., 2004 \\
\hline Rapeseed plant & 57.29 & 6.63 & 34.08 & 1.03 & nd & 1.96 & 0.265 & nd & nd & nd & nd & nd & nd & Karaosmanoglu et al., 1999 \\
\hline Pine needles & 45.81 & 5.38 & 46.11 & 0.98 & nd & 1.41 & 0.755 & nd & 78.54 & nd & nd & nd & 900 & Ren et al., 2009 \\
\hline Rice straw & 45.14 & 5.85 & 46.69 & 0.62 & nd & 1.56 & 0.793 & 8.19 & 61.00 & 15.39 & 12.80 & oxygen bomb calorimeter & 750 & Ren et al., 2009 \\
\hline Sunflower shell & 47.40 & 5.80 & 41.40 & 1.40 & nd & 1.47 & 0.655 & 7.1 & nd & 20.25 & 4.7 & calorimeter & 850 & Demirbas, 2006 \\
\hline Jute stick & 47.18 & 8.36 & 44.1 & nd & nd & 1.96 & 0.085 & nd & 74.58 & nd & nd & calorimeter & 1000 & Islam et al., 2005 \\
\hline Wheat straw & 47.33 & 2.55 & 48.12 & 0.79 & nd & 0.63 & 0.748 & 8.5 & 75.00 & 18.25 & 3.4 & calorimeter & 800 & Ren et al., 2009 \\
\hline
\end{tabular}

nd - not determined; C, H, O, N and S all are in \% terms. HHV and MC refers to high heating value and moisture content respectively 
contains xylan) is thermally pyrolyzed to furfural, methanol, acetic acids, acetones, and phenols. Ketones and acids are converted in catalytic pyrolysis to phenols, aromatic hydrocarbons, and polycyclic aromatic hydrocarbons (Zhang et al., 2007). Lignin gets decomposed into phenolic compounds which cannot be altered catalytically due to the presence of the aromatic phenol structure. However, the phenolic structure is converted into new compounds in catalytic pyrolysis (Kabir and Hameed, 2017; Dong and Xiong 2014). Direct combustion is the most used and oldest process to obtain energy; it can also be used to dry of agricultural products and to generate steam and heat (Saidur et al., 2011).

\section{Conventional pyrolysis}

Pyrolysis is a thermal process by which an organic substance is decomposed at elevated temperatures and in the absence of oxygen (Fig. 3). Pyrolysis converts lignocellulosic biomass to bio-oil which is a precursor to fuels. The high oxygen content of bio-oil deteriorates its fuel properties. Catalytic pyrolysis of lignocellulose biomass to upgrade bio-oil through selected bond cleavage reactions such as deoxygenation, cracking, decarbonylation, and other reactions has been investigated to date. Batch, semi-batch, and continuous processes are commonly used for bio-oil production by biomass pyrolysis (Kabir and Hameed, 2017).

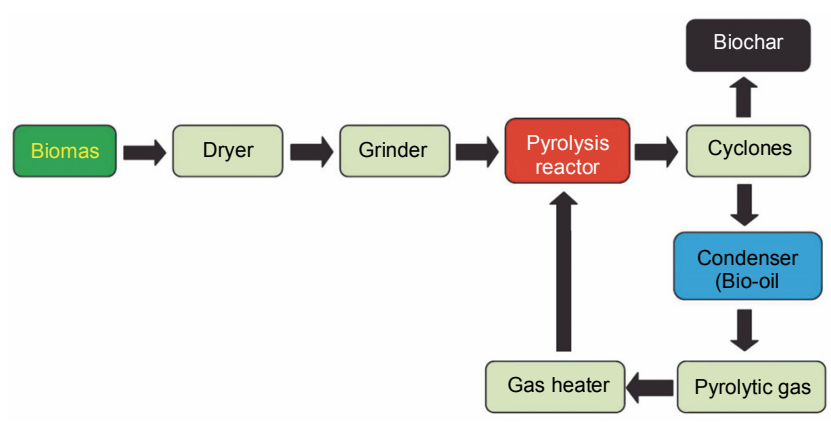

Fig. 3. Fast pyrolysis process flow (Beneroso et al., 2017)

\section{Fast pyrolysis}

Fast Pyrolysis technology can be used for volatilizing a broad range of feedstock from organic wastes to plastics. This decomposition, which is irreversible and generates three types of products i.e., bio-oil, gases, and char, leads to variations in the chemical composition and physical characteristics of the biomass produced (Neves et al., 2011). Pyrolysis is classified as slow, intermediate, and fast depending on various parameters like the rate of heating, residence time, feed rate, and reaction temperature. Both slow and the intermediate pyrolysis are performed below $500^{\circ} \mathrm{C}$, but fast pyrolysis is performed at $500-700^{\circ} \mathrm{C}$ (Park et al., 2014). Fast pyrolysis generates a higher amount of cellulose and hemicellulose content when compared to lignin (Zhang, 2007; Chen et al., 2011). It typically involves a higher heating rate $\left(10-200^{\circ} \mathrm{C} / \mathrm{s}\right)$ for a particle size $<2 \mathrm{~mm}$ and a very short residence time ( $<2 \mathrm{~s})$ (Demirbas, 2001; Safi et al., 2004). Bio-oil obtained from fast pyrolysis is a dark coffee-colored liquid, mainly composed of carboxylic acids, water (15-35 wt\%), chemical components, and carbohydrates, which can further be recovered from the chemical or food industry (Yanik et al., 2007; Karaosmanogly et al., 1999). The calorific value of bio-oil ranges from 15 to $38 \mathrm{MJ} / \mathrm{kg}$ (Asadullah et al., 2007). The gaseous product of pyrolysis is called synthesis gas (syngas), and it primarily contains $\mathrm{CO}_{2}, \mathrm{CO}, \mathrm{CH}_{4}$, and $\mathrm{H}_{2}$ with a gross calorific value of $6.4-9.8 \mathrm{MJ} / \mathrm{kg}$. It can be used for heating the biomass during pyrolysis, and is considered a significant gas for drying the biomass in the pyrolysis process (Islam et al., 2005; Tekin et al., 2014). It is presented in Figure 4 (Quispe et al., 2017).

\section{Microwave pyrolysis}

Conventional heating requires energy supply to the biomass by heat transfer but microwave heating occurs through biomass interaction with the electric field, a component of electromagnetic waves. Thus, microwaves provide direct electromagnetic energy transfer that leads to instantaneous and volumetric heating (Bermúdez et al., 2015). Therefore, particle size is reduced without energy and without requiring pre-treatment, unlike in the conventional pyrolysis technique (Fig. 5). When compared to conventional pyrolysis, microwave heating provides various advantages such as enhanced quality of biomass derivatives and a simpler process, (Fig. 6). Microwave pyrolysis of biomass is of much importance in bioenergy research. Microwave pyrolysis can be scaled up in terms of high power density, very low residence time, and continuous operation mode (Beneroso et al., 2017; Önal et al., 2011).

\section{Hydrothermal liquefaction}

Hydrothermal liquefaction is a method of obtaining bio-oil from biomass at a moderate-to-high temperature 


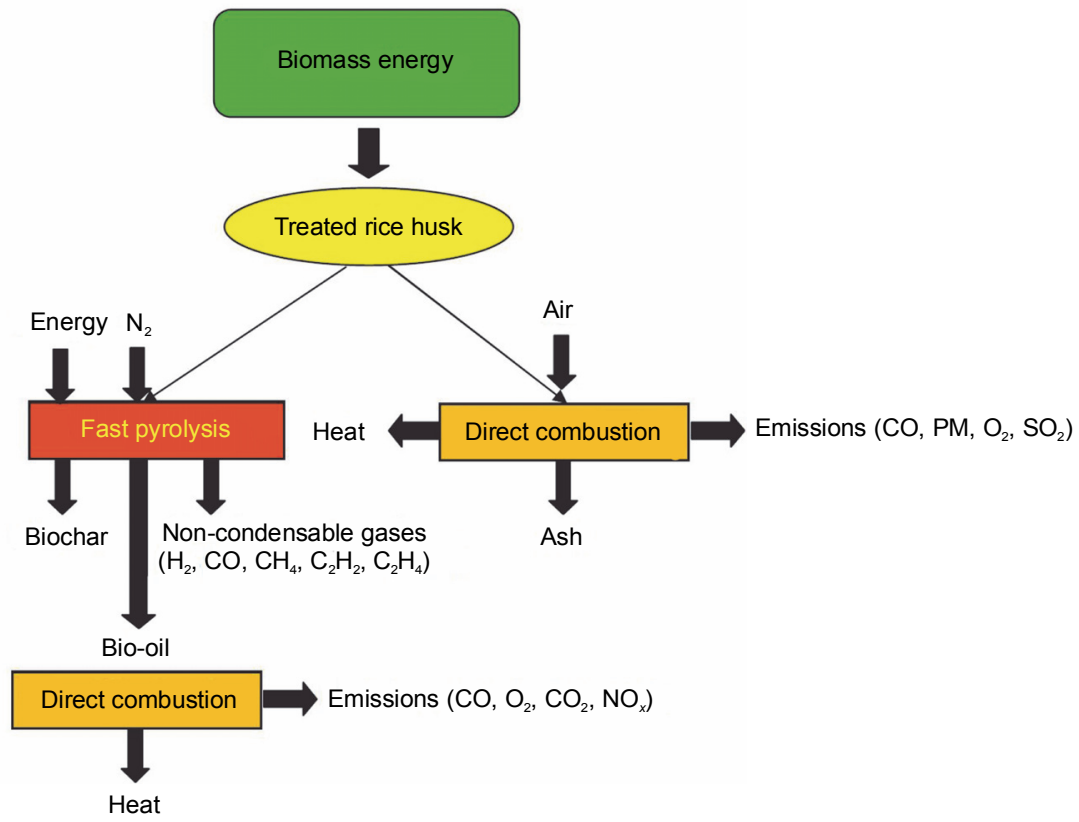

Fig. 4. Direct combustion and fast pyrolysis processes (PM: particulate matter) (Quispe et al., 2017)

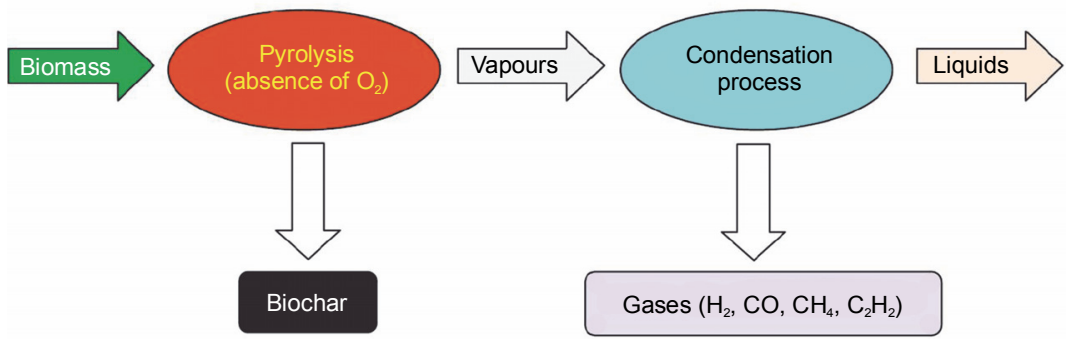

Fig. 5. Pyrolysis process scheme (Quispe et al., 2017)

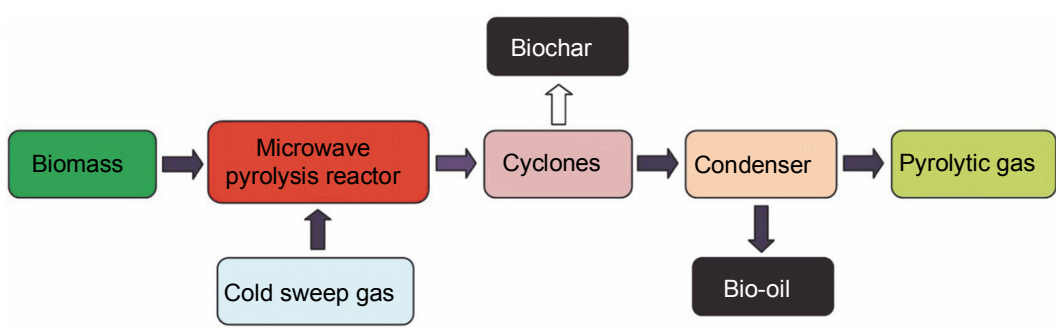

Fig. 6. Microwave pyrolysis process flow diagram (Beneroso et al., 2017)

$\left(250-550^{\circ} \mathrm{C}\right)$ and pressure $(5-25 \mathrm{MPa})$ in the presence of a solvent in a batch reactor (Akhtar and Amin, 2011). A vast amount of literature is available to show the role of alkaline or neutral conditions in hydrothermal liquefaction of biomass to bio-oil (Yin, and Tan, 2012). Xu and coworkers (2014) investigated the hydrothermal liquefaction of Chlorella pyrenoidosa catalyzed by Ce/HZSM- 5 for the production of bio-oil. It is a thermochemical conversion technique used to convert biomass into liquid fuels, and is shown in Figure 7.

Hydrothermal liquefaction (HTL) helps in direct conversion of wet biomass to liquid bio-crude ( $\mathrm{Yu}$ et al., 2009). The thermochemical reaction takes place on wet biomass in water under critical conditions, i.e., process 


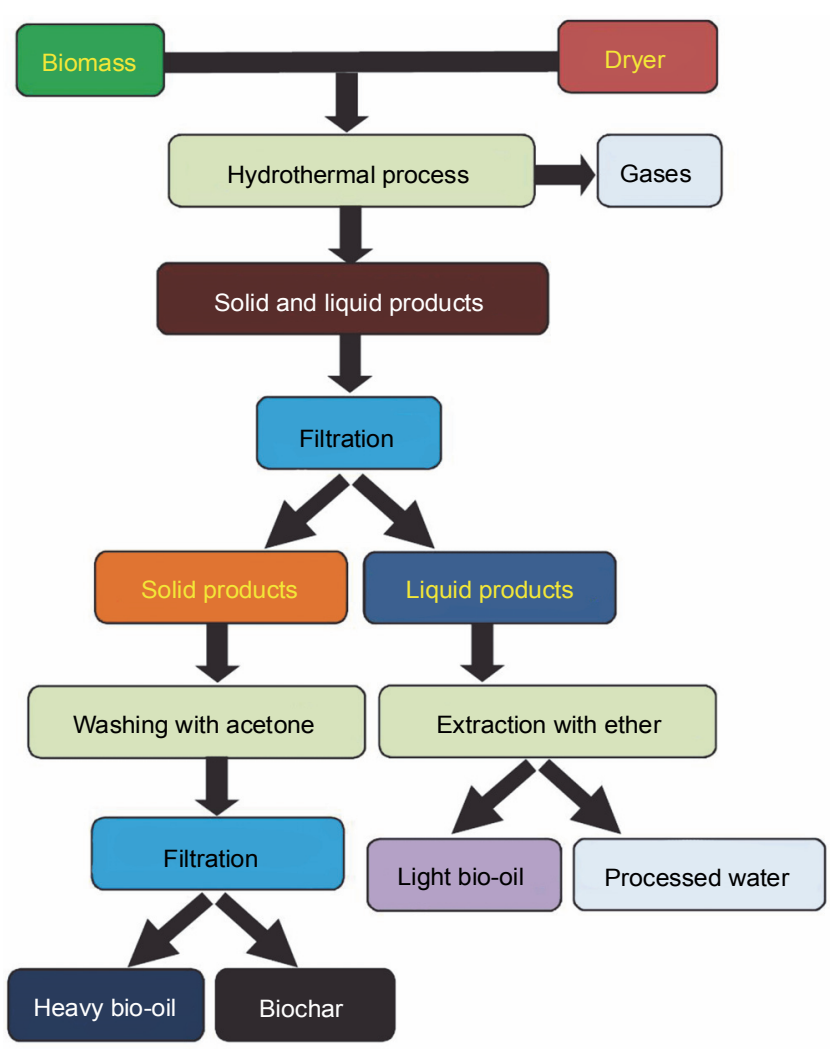

Fig. 7. Hydrothermal processing of biomass (Tekin et al., 2014)

temperatures $270-370^{\circ} \mathrm{C}$ and pressures of $10-25 \mathrm{MPa}$ (<2 MPa: hydrothermal carbonization) (Li et al., 2011; Elliott et al., 2013). HTL oil has approximately $10-20 \% \mathrm{w} / \mathrm{w}$ of nitrogen and oxygen, and the energy density in the range 30-37 $\mathrm{MJ} \mathrm{kg}^{-1}$ (Yang et al., 2009; Maggi and Delmon, 1994). Macroalgae have also attracted attention as a feedstock for biofuels. In a study of fast pyrolysis of Saccharina japonica at $350^{\circ} \mathrm{C}$, the highest bio-oil yield of $44.9 \%$ was obtained (Ly et al., 2015). Non-catalytic tests performed on Cladophora glomerata resulted in the highest bio-oil production at $500^{\circ} \mathrm{C}$ (Norouzi et al., 2016).

\section{Hydrothermal torrefaction}

Hydrothermal torrefaction is a promising method for dealing with wet organic matter such as agricultural and forestry residuals, animal manure, and human waste $(\mathrm{Xu}$ et al., 2018). The wet torrefaction technique is used to produce high bio-oil yield at mild reaction conditions in the temperature range of 150 to $240^{\circ} \mathrm{C}$ in $60 \mathrm{~min}$ using rice husk (Zhang et al., 2017; Wang et al., 2018c). Torrefaction decreases the oxygen content of the solid product. It has been observed that bio-oil obtained from bio- mass pyrolysis is unstable and low industrial use is due to the high oxygen content (He et al., 2018).

\section{Gasification}

Gas production via bio-oil gasification acts as a bridge between bio-oil and transportation fuel. Biooil gasification is performed by using the air stream as a gasifying agent (Zheng et al., 2018). Gasification of biomass and bio-oil produces syngas which can be transformed into diesel by the Fischer-Tropsch synthesis (Bulushev and Ross, 2011). Figure 8 shows the use of biomass gasification for fuels.

\section{Parameters influencing conversions}

\section{Reaction atmosphere}

An inert atmosphere is required for the pyrolysis of biomass. However, other gases can also be used for this purpose (Putun et al., 2008). Steam performs partial gasification as it may weakly oxidize the biomass. As compared to other atmospheres, under $\mathrm{H}_{2}$ atmosphere, the HHV of the bio-oil may reach the highest value of $24.4 \mathrm{MJ} / \mathrm{kg}$ while oxygen in the biomass is converted to $\mathrm{H}_{2} \mathrm{O}$. In another study, the effects of $\mathrm{CO}_{2}, \mathrm{CH}_{4}, \mathrm{CO}$, and $\mathrm{N}_{2}$ atmospheres were observed in a fluidized bed reactor to assess the potential use of the gasifying medium (Guizani et al., 2014).

\section{Temperature}

Pyrolysis temperature influences the properties and distribution of products. Generally, peak concentrations of bio-oil yields can be obtained in a temperature range of $400-550^{\circ} \mathrm{C}$, and it declines as the temperature is increased. When the temperature exceeds $600^{\circ} \mathrm{C}$, some parts of bio-oils and biochar products get converted into gas due to secondary cracking reactions (Li et al., 2007). With further increase in temperature i.e., above $700^{\circ} \mathrm{C}$, the carbon content of bio-oil increases (Ates et al., 2008).

\section{Heating rate}

Heating rate is an essential parameter for bio-oil production during pyrolysis. It defines the type of biomass pyrolysis i.e., fast, flash and slow pyrolysis. Fast heating rates are more favorable for higher of yields of gases and faster fragmentation with a low production of char. Similarly, bio-oil yield also gets enhanced at fast heating rates due to reduction of mass for secondary reactions. In an 


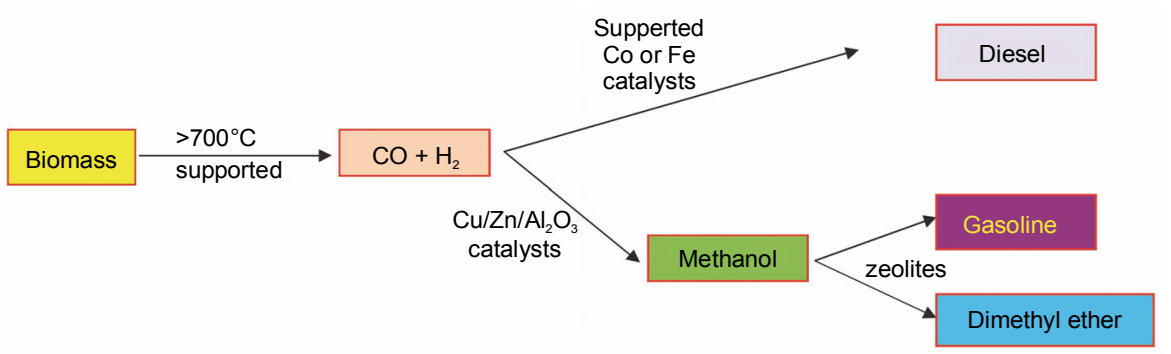

Fig. 8. Showing the use of biomass gasification to give fuels (Bulushev and Ross, 2011)

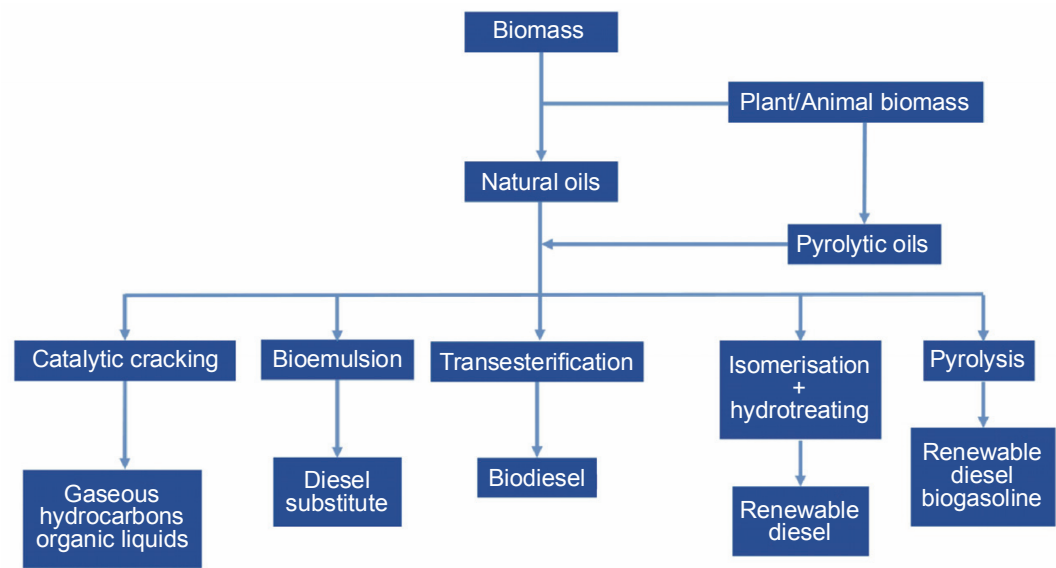

Fig. 9. Biomass conversion to biofuels (Isa and Ganda, 2018)

experiment performed on sawdust, it was observed that when the heating rate was increased beyond $500^{\circ} \mathrm{C} / \mathrm{min}$, the bio-oil yield increased by $8 \%$. Furthermore, when the heating rate was increased to $1000^{\circ} \mathrm{C} / \mathrm{min}$, no change in bio-oil yield was observed due to heat and mass transfer limitations (Salehi et al., 2009).

\section{Residence time}

Bio-oil production requires a shorter residence time to minimize secondary reactions in the reactor. In an experiment performed on the pyrolysis of raw sorghum bagasse at $525^{\circ} \mathrm{C}$, an increase in residence time from 0.2 to $0.9 \mathrm{~s}$ resulted in a decrease in bio-oil yield from 75 to $57 \%$ (Scott et al., 1999).

\section{Pressure}

Pressure influences the quality of the product formed in pyrolysis. High pressure promotes deoxygenation of bio-oil and increases its combustible performance (Paysepar et al., 2018). A study performed on pressurized pyrolysis of wheat straw indicated the significant influence of reactor pressure on both the quality of the product and the yield. However, only a narrow range of pressures was considered, 0.0689 bar (10 psi) to 2.758 bar (40 psi). Mahinpey et al. (2009) concluded that the optimum pressure for wheat straw pyrolysis was 1.379 bar (20 psi).

\section{Catalysts}

Homogeneous catalysts (such as $\mathrm{KOH}, \mathrm{Na}_{2} \mathrm{CO}_{3}$, and alkaline salts) and heterogeneous catalysts (such as $\mathrm{Pd} / \mathrm{C}$, $\mathrm{Pt} / \mathrm{C}, \mathrm{Ru} / \mathrm{C}, \mathrm{Ni} / \mathrm{SiO}_{2}-\mathrm{Al}_{2} \mathrm{O}_{3}, \mathrm{CoMo} / \gamma-\mathrm{Al}_{2} \mathrm{O}_{3}$, zeolites, and $\mathrm{Fe}$ ) improve bio-oil quality (Mostafazadeh et al., 2018). Various catalysts help to form products with different properties at the same temperature and from the same raw material (Valle et al., 2013). These compounds have a higher thermal stability, an acidic site, excellent activity, a large surface area, and good shape selectivity for hydrocarbons, thereby enhancing bio-oil production.

\section{Bio-oil applications}

Thermal cracking, hydro treatment, and catalytic cracking are the conventional methods of upgrading biooil (Ma et al., 2018). Petroleum range hydrocarbons can 
be produced by the secondary processing of bio-oils through the use of various catalysts like metals, metal carbonates, and oxides, and aluminosilicates (Isa and Ganda, 2018). Biomass conversion to biofuels is shown in Figure 9 (Isa and Ganda, 2018). Bio-oil can be used as an alternative source of fuel in various applications like engines, turbines, furnaces, and boilers for heat and electricity generation (Shihadeh and Hochgreb, 2002).

\section{Electricity production}

The use of bio-oil requires engine modifications, primarily due to its high acidic value. Major changes in the linings, pumps, and injection systems of engines are necessary for the use of bio-oils. Bio-oil blended with standard bio-diesel fuels is also achievable (Bertero et al., 2014).

\section{Heat production}

The heating value of bio-oil is less in comparison to fossil fuels because of the amount of oxygenated compounds present and a considerable water content. However, flame combustion tests have proved that fast pyrolysis oils can substitute backlight and heavy fuel oils in industrial boiler applications (Bridgwater, 2003).

\section{Chemicals obtained from Bio-oil}

More than 300 compounds are recognized as wreckage from the essential components present in biomass like the cellulose, lignin, and cellulose derivatives. The only commercially significant application of chemicals obtained from bio-oil is liquid smoke or wood flavor (Montazeri et al., 2013; Akharume et al., 2019; Boocock et al., 2001).

\section{Transport fuels}

The limitations of bio-oil fuels include high viscosity, chemical instability, heating value, and incomplete volatility. To enhance the quality of bio-oil as transport fuel, the application of simple physical methods is necessary. Surfactants are mixed in pyrolysis oil so that it can be emulsified with diesel fuel. In Canada, the microemulsion technique is being used with $5-30 \%$ bio-oil at the University of Florence to convert bio-oil to transport fuel (Baloch et al., 2018; Baglioni et al., 2001).

\section{Reactor type}

To maximize the yield of bio-oil with a wide variety of feedstocks, efforts are being made to develop and test different reactor configurations based on different fluid dynamics. It has been estimated that the initial investment for the reactor configuration represents approximately $10-15 \%$ of the total capital cost of the pyrolysis process (Bilbao et al., 2018). Various types of bioreactors are used in pyrolysis systems; they are fixed bed, Heinze-type reactor, Auger reactor, vacuum pyrolysis, ablative pyrolyzer, rotating cone pyrolyzer, circulating fluidized bed/transport reactor, and bubbling fluidized bed. Similarly, for a slow pyrolysis system, microwave and tubular reactors are specifically used. An overview of the work done in slow and fast pyrolysis on various biomass sources is presented in Table 3. Major highlights of significant reactors are as below.

\section{Bubbling fluidized bed reactor}

A bubbling fluidized bed reactor is made of stainless steel pipes, and nitrogen is used as the fluidizing medium introduced via a $100 \mu \mathrm{m}$ porous gas distributor. The system uses silica sand and dolomite with a particle size $180-250 \mu \mathrm{m}$ as the fluidized bed material (Ly et al., 2018; Wang et al., 2018b). These are simple fluidized reactor beds with modifications as opposed to circulating fluidized beds (Fig. 10). These are simple to operate and construct, and in addition, they provide efficient heat transfer with good temperature control because of the presence of high solid density. Sand is often used for the solid phase. These beds increase the yield of good quality bio-oil. Moreover, char accumulation is negligible and is eluted rapidly (Ren et al., 2009; Ly et al., 2015; Lu et al., 2008; Miranda et al., 2009).

\section{Circulating fluidized beds}

The circulating fluidized bed has features similar to that of a bubbling bed reactor. The residence time of vapor and char is approximately similar (Pütün et al., 2005). The majority of circulating beds appear to be dilute phase units. As they are dependent primarily on gas, their heat transfer rates are very low (Ambler et al., 1990). Biomass ash, also known as a cracking catalyst, causes a loss of volatile particles in bio-oil yield. This technique is majorly used in the petrochemical and petroleum industry (Reyhanitash, 2013).

\section{Vacuum pyrolysis reactors}

The heat transfer rate of a solid biomass is much lower in vacuum pyrolysis reactors when compared with 
Table 3. Various reactors used for different biomass

\begin{tabular}{|c|c|c|c|c|c|c|c|c|c|c|c|c|c|c|}
\hline $\begin{array}{c}\text { Type } \\
\text { of } \\
\text { pyrolysis }\end{array}$ & $\begin{array}{l}\text { Reactor } \\
\text { type }\end{array}$ & System & Reactor configurations & $\begin{array}{l}\text { Biomass } \\
\text { type }\end{array}$ & $\begin{array}{c}\text { Cellulose } \\
{[\%]}\end{array}$ & $\begin{array}{c}\text { Hemi- } \\
\text { cellulose } \\
{[\%]}\end{array}$ & $\begin{array}{c}\text { Lignin } \\
{[\%]}\end{array}$ & $\begin{array}{l}\text { Yield } \\
{[\%]}\end{array}$ & $\begin{array}{c}\text { Tempera- } \\
\text { ture } \\
{\left[{ }^{\circ} \mathrm{C}\right]}\end{array}$ & Pressure & $\begin{array}{c}\text { Carrier } \\
\text { gas } \\
\text { need }\end{array}$ & $\begin{array}{l}\text { Catalyst } \\
\text { type }\end{array}$ & $\begin{array}{l}\text { Residence } \\
\text { time }\end{array}$ & Reference \\
\hline \begin{tabular}{l|} 
Slow \\
pyrolysis
\end{tabular} & $\begin{array}{l}\text { tubular } \\
\text { reactor }\end{array}$ & batch & $\begin{array}{l}\text { made up of stainless steel, height } \\
800 \mathrm{~mm} \text {, inner dia. } 20 \mathrm{~mm}\end{array}$ & $\begin{array}{l}\text { banana } \\
\text { peel }\end{array}$ & 15.07 & 34.8 & 15.98 & 0.35 & 250 & $1 \mathrm{~atm}$ & low & ZSM-5 & - & Onal et al., 2011 \\
\hline \begin{tabular}{l|} 
Slow \\
pyrolysis
\end{tabular} & $\begin{array}{c}\text { semi- } \\
\text { continuous }\end{array}$ & batch & - & $\begin{array}{l}\text { orange } \\
\text { peel }\end{array}$ & 17.58 & 28.58 & 12.39 & 53.9 & 250 & - & low & zeolite & - & Miranda et al., 2009 \\
\hline $\begin{array}{l}\text { Slow } \\
\text { pyrolysis }\end{array}$ & $\begin{array}{l}\text { Heinze } \\
\text { type } \\
\text { reactor }\end{array}$ & batch & - & $\begin{array}{l}\text { cotton } \\
\text { stalk }\end{array}$ & 25.3 & 27.8 & 24 & 0.2382 & 300 & - & low & $\mathrm{ZnCl}_{2}$ & - & $\begin{array}{l}\text { Dickerson } \\
\text { and Soria, } 2013\end{array}$ \\
\hline $\begin{array}{l}\text { Slow } \\
\text { pyrolysis }\end{array}$ & $\begin{array}{l}\text { fixed } \\
\text { bed }\end{array}$ & batch & - & $\begin{array}{l}\text { micro- } \\
\text { algae }\end{array}$ & 36.64 & 4.82 & 39.61 & 0.4636 & 450 & $20 \mathrm{Mpa}$ & high & - & $30 \mathrm{~min}$ & $\begin{array}{l}\text { Mohamed et al., } \\
2013\end{array}$ \\
\hline $\begin{array}{l}\text { Fast } \\
\text { pyrolysis }\end{array}$ & $\begin{array}{c}\text { bubbling } \\
\text { fuidized } \\
\text { bed }\end{array}$ & continuous & $\begin{array}{l}\text { made up of alumina tube, height } \\
2.3 \mathrm{~m} \text {, dia. } 0.075 \mathrm{~m}\end{array}$ & $\begin{array}{l}\text { wheat } \\
\text { straw }\end{array}$ & 16 & 26 & 29 & 0.55 & 450 & $10 \mathrm{bar}$ & high & Al-SBA-15 & $15-30 \mathrm{~min}$ & $\begin{array}{l}\text { Karoasmanoglu } \\
\text { et al., } 1999\end{array}$ \\
\hline $\begin{array}{l}\text { Fast } \\
\text { pyrolysis }\end{array}$ & $\begin{array}{c}\text { circulating } \\
\text { fluidized } \\
\text { bed }\end{array}$ & continuous & $\begin{array}{l}\text { made up of } 316 \text { stainless steel, } \\
\text { height } 915 \mathrm{~mm} \text {, bed diameter } \\
30 \mathrm{~mm}\end{array}$ & $\begin{array}{l}\text { corn } \\
\text { cob }\end{array}$ & 41.7 & 30.84 & 30.1 & 34.0 & 500 & $30 \mathrm{Mpa}$ & high & zeolite & $5 \mathrm{~min}$ & $\begin{array}{l}\text { Cao et al., 2004; } \\
\text { Lu et al., } 2008\end{array}$ \\
\hline $\begin{array}{l}\text { Fast } \\
\text { pyrolysis }\end{array}$ & $\begin{array}{c}\text { tubular } \\
\text { bowl }\end{array}$ & continuous & $\begin{array}{l}\text { stainless steel, diameter } 125 \mathrm{~mm} \text {, } \\
\text { height } 500 \mathrm{~mm}\end{array}$ & $\begin{array}{l}\text { pine } \\
\text { wood }\end{array}$ & 46.4 & 31.7 & 21.9 & 42 & 500 & - & low & $\begin{array}{c}\text { BEA } \\
\text { zeolite }\end{array}$ & $0.5 \mathrm{~s}$ & $\begin{array}{l}\text { Jand and Foscolo, } \\
2005\end{array}$ \\
\hline $\begin{array}{l}\text { Fast } \\
\text { pyrolysis }\end{array}$ & ablative & batch & - & $\begin{array}{l}\text { saw } \\
\text { dust }\end{array}$ & 15.25 & 25.58 & 13.25 & 45 & 750 & - & low & $\mathrm{Al}_{2} \mathrm{O}_{3}$ & - & Reddy et al., 2014 \\
\hline \begin{tabular}{l|} 
Fast \\
pyrolysis
\end{tabular} & $\begin{array}{l}\text { fluidized } \\
\text { bed }\end{array}$ & continuous & $\begin{array}{l}\text { cylindrical horizontal, height } 3 \mathrm{~m} \\
\text { long, } 0.6 \mathrm{~m} \text { diameter }\end{array}$ & $\begin{array}{c}\text { sugarcane } \\
\text { bagasse }\end{array}$ & 20 & 25 & 42 & $38-48$ & 550 & $8 \mathrm{Kpa}$ & high & - & $0.5 \mathrm{~s}$ & Putun et al., 2005 \\
\hline $\begin{array}{l}\text { Fast } \\
\text { pyrolysis }\end{array}$ & $\begin{array}{c}\text { fixed } \\
\text { bed }\end{array}$ & continuous & $\begin{array}{l}\text { made up of high temperature } \\
\text { stainless steel }\end{array}$ & $\begin{array}{l}\text { almond } \\
\text { shell }\end{array}$ & 29 & 28 & 35 & 41.3 & 550 & $2.5 \mathrm{bar}$ & high & $\mathrm{CaO}$ & $30 \mathrm{~min}$ & Gomez et al., 2009 \\
\hline $\begin{array}{l}\text { Fast } \\
\text { pyrolysis }\end{array}$ & batch & continuous & - & $\begin{array}{l}\text { olive } \\
\text { husk }\end{array}$ & 22.5 & 21.1 & 44.9 & 18.0 & 500 & $0.21 \mathrm{bar}$ & low & $\mathrm{Na}_{2} \mathrm{CO}_{3}$ & - & $\begin{array}{l}\text { Zabaniotou et al., } \\
2000\end{array}$ \\
\hline $\begin{array}{l}\text { Fast } \\
\text { pyrolysis }\end{array}$ & $\begin{array}{l}\text { fluidized } \\
\text { bed }\end{array}$ & continuous & made up of alumina tube & $\begin{array}{l}\text { rice } \\
\text { husk }\end{array}$ & 34.0 & 27.2 & 14.2 & 0.2711 & 500 & $350 \mathrm{Mpa}$ & high & $\mathrm{Al}_{2} \mathrm{O}_{3}$ & $2-3 \mathrm{~s}$ & $\begin{array}{l}\text { Park et al., 2008; } \\
\text { Chen et al., 2011 }\end{array}$ \\
\hline $\begin{array}{l}\text { Fast } \\
\text { pyrolysis }\end{array}$ & $\begin{array}{l}\text { fixed } \\
\text { bed }\end{array}$ & batch & - & $\begin{array}{l}\text { potato } \\
\text { skin }\end{array}$ & 15.07 & 31.45 & 14.58 & 0.1386 & 550 & $20 \mathrm{Mpa}$ & high & - & - & Ji-lu et al., 2007 \\
\hline
\end{tabular}




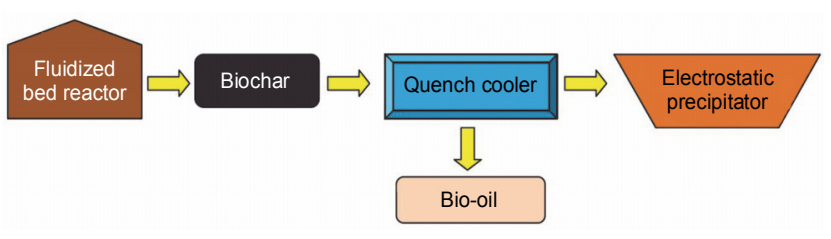

Fig. 10. Bubbling fluidized bed reactor (Mohan et al., 2006)

other reactors. During the thermal decomposition of the biomass under reduced pressure, complex molecules in the reactor break down into simpler ones. These smaller fragments are swiftly withdrawn by vacuum, and are further recovered as pyrolytic oil (Li et al., 2007). The process is performed at approx. $450^{\circ} \mathrm{C}$ at a total pressure of $15 \mathrm{KPa}$. The major advantage is that volatiles can achieve short residence times. Thus, the biomass particle residence time does not couple with that of volatile particles (Bridgwater, 2019; Bridgwater, 1999).

\section{Ablative pyrolysis reactors}

The ablative process depends on the heat transfer that occurs when any particle from the biomass slides over a solid heat source. Here, the reaction is limited by the rate of heat transfer to the biomass particle; therefore, small particles are essential. The principle behind this reactor is scraping a stream of biomass particles over a heated surface. The conditions required are high pressure and high relative motion (Mohan et al., 2006).

\section{Fixed bed reactors}

Fixed bed bioreactors may be used to maximize the bio-oil yield. The reactor tube is made of stainless steel and is heated independently by an electric furnace to ensure an isothermal region in the reactor. David and Kopac (2018) demonstrated that the bio-oil produced from rapeseed oil cake at a pyrolysis temperature of $500^{\circ} \mathrm{C}$ results in $34.6 \%$ yield. The calorific value of the bio-oil produced at $500^{\circ} \mathrm{C}$ was $33.13 \mathrm{MJ} / \mathrm{kg}$ which is similar to that of coal. In another research, cotton stalk was used for pyrolysis to obtain bio-oil with a maximum yield of $55 \%$ at $510^{\circ} \mathrm{C}$ (Li et al., 2007).

\section{Kinetic modeling study of the bio-oil formation}

Biomass degradation requires comprehensive models for the kinetic mechanisms. These mechanisms require chemical equations for both mass and heat transfer. To determine the kinetic parameters, model fitting, or isoconversional models are used. Model fitting models are classified as either one-component or multi-component (Resende et al., 2010). In one component modeling of the formation of tar, char and gases occur from the biomass in a single, independent, and global reaction mechanism. But multi-component modeling characterizes the initial biomass of lignin, cellulose, and hemicelluloses (Ranzi et al., 2014). The former is mainly related to thermo gravimetric analysis (TGA). TGA helps in proximate analysis (fixed carbon, ash content, moisture, volatile content) and also studies the kinetic mechanism of pyrolysis. Here, weight change in the biomass sample is measured under isothermal (mass loss vs time) or nonisothermal conditions (mass loss vs temperature). Every pyrolysis model helps to describe the process with mathematical expressions which rely on either system components (mechanistic model) or experimental data (empirical model). Pyrolysis models are called pseudo mechanistic models. The multi-component model is based on the devolatilization reaction of biomass components (lignin, cellulose, or hemicellulose) and secondary phase pyrolysis reactions. This model is suitable for a wide range of biomasses as long as biomass characterization is performed properly. In this process, it is generally assumed that there is no interaction between the components of the biomass. A simplified detail of biomass is given as elemental analysis $(\mathrm{C}, \mathrm{H}, \mathrm{N}, \mathrm{O}, \mathrm{S})$, proximate analysis and biochemical analysis.

In a recent research, the detailed chemistry of the devolatilization of cellulose, hemicelluloses,, and lignin was studied using Gas chromatography-mass spectrometry (Azeez et al., 2010).

The research was performed on a cellulose sample to observe the kinetics of pyrolysis; cellulose degradation was assumed to be occurring with first-order reaction kinetics. Cellulose is degraded into a) volatiles (condensed fraction) and $b$ ) gaseous and char fractions (includes carbon monoxide, water, and carbon dioxide), with $\mathrm{k}_{\mathrm{v}}$ and $\mathrm{k}_{\mathrm{c}}$ being the respective rate constants. Figure 11 shows the kinetics of cellulose pyrolysis.

$W_{\text {cell }}, W_{\mathrm{c}}, W_{\mathrm{g}}, W_{\mathrm{v}}$ are the normalized weights of cellulose, char, gases, and volatiles, respectively. Also, $W_{\text {cell }}$ $+W_{\mathrm{c}}+W_{\mathrm{g}}+W_{\mathrm{v}}=1$. Further, by using the rate equation

$$
-\mathrm{d} W_{\text {cell }} / \mathrm{d} t=\left(k_{\mathrm{v}}+k_{\mathrm{c}}\right)\left[W_{\text {cell }}\right] .
$$




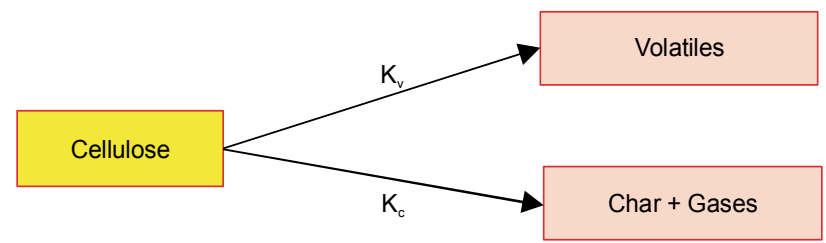

Fig. 11. Kinetics of cellulose pyrolysis (Resende and Savage, 2010)

Hence, modifications were made to the kinetic model as shown in Figure 12, which revealed cellulose thermal decomposition kinetics.

The rate constants $k_{\mathrm{v}}$ and $k_{\mathrm{c}}$ are expressed by the Arrhenius equation:

$$
k_{\mathrm{v}}=1.9 \times 10^{16} \times \mathrm{e}^{-(47300 / \mathrm{RT})} \mathrm{min}^{-1}
$$

and

$$
k_{\mathrm{c}}=7.9 \times 10^{11} \times \mathrm{e}^{-(36600 / \mathrm{RT})} \mathrm{min}^{-1}
$$

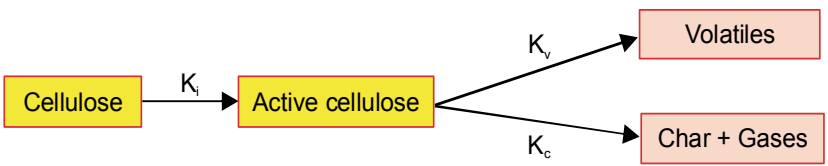

Fig. 12. Cellulose thermal decomposition kinetics (Resende and Savage, 2010)

This suggests that cellulose does not get converted directly to volatiles but undergoes intermediate chemical and physical changes during pyrolysis (Resende and Savage, 2010).

\section{Conclusions}

The rising concerns about depleting fossil fuels and greenhouse gas limits have resulted in a great interest in non-conventional fuels originating from bio-renewable sources including sugars, starches, lignocellulosic materials, and algal biomasses. Bioenergy crops can be grown for two contrasting markets: power generation (electricity, heat, and combined heat and power), and liquid transport fuels. Although, over one billion tons of biomass per year would be potentially available to meet the $30 \%$ replacement requirement of petroleum-derived gasoline in 2030, the high cost of biomass could be a serious issue if potential lands and feedstocks are not managed and utilized efficiently. Biofuels such as ethanol, butanol, hydrogen gas etc. produced from various lignocellulosic materials such as wood and agricultural, and forest residues have the potential to be a valuable substitute for, or complement to, gasoline. The review describes technologies such as direct combustion, microwave technology, HTL, and fast pyrolysis to convert biomass into bio-oil. Current research is mainly focused on the use of catalysts to enhance bio-oil production and quality. Various parameters affect the biomass pyrolysis process, properties, and yields of products. These generally include the biomass source, biomass pretreatment (physical, chemical, and biological), the catalyst, the reaction atmosphere, temperature, the heating rate, as well as the pressure and vapor residence time. In industrialized countries, direct combustion technology is mainly used because of its economic viability. Currently, a new biomass-based economy may be established by developed countries by incorporating bio-oil into refinery units to fulfil the market demand of fuels. The assessment of the potential economic impact of biomass on the fuel industry should account for the limited availability of biomass. Biomass-based technology, which is still in a nascent stage, cannot compete with conventional fossil fuels. Further research is required to design and implement new units for upgrading raw bio-oil within the scope of the petrochemical industry.

\section{Authors' contributions}

All the authors contributed equally to the preparation of the manuscript. All authors have read and approved the final manuscript.

\section{References}

Adhikari S., Srinivasan V., Fasina O. (2014) Catalytic pyrolysis of raw and thermally treated lignin using different acidic zeolites. Energy Fuels 28(7): 4532-4538. DOI: 10.1021/ ef500902x.

Ahmad M.I., Zhang N., Jobson M. (2011) Integrated design of diesel hydrotreating processes. Chem. Eng. Res. Design, 89(7): 1025-1036. DOI: 10.1016/j.cherd.2010.11.021.

Akharume F., Singh K., Sivanandan L. (2019) Effects of liquid smoke infusion on osmotic dehydration kinetics and microstructural characteristics of apples cubes. J. Food Eng. 246: 51-57.

Akhtar J., Amin N.A.S. (2011) A review on process conditions for optimum bio-oil yield in hydrothermal liquefaction of biomass. Renew. Sustain. Energy Rev. 15(3): 1615-1624.

Ambler P.A., Milne B.J., Berruti F., Scott D.S. (1990) Residence time distribution of solids in a circulating fluidized bed: experimental and modelling studies. Chem. Eng. Sci. 45(8): 2179-2186. DOI: 10.1016/0009-2509(90)80093-T. 
Asadullah M., Rahman M.A., Ali M.M., Rahman M.S., Motin M.A., Sultan M.B., Alam M.R. (2007) Production of bio-oil from fixed bed pyrolysis of bagasse. Fuel 86(16): 2514-2520. DOI: 10.1016/j.fuel.2007.02.007.

Ates F., Isịkdağ M.A. (2008) Evaluation of the role of the pyrolysis temperature in straw biomass samples and characterization of the oils by $G C / M S$. Energy Fuels 22(3): 1936-1943. DOI: 10.1021/ef7006276.

Aysu T. (2015) Catalytic pyrolysis of Eremurus spectabilis for bio-oil production in a fixed-bed reactor: effects of pyrolysis parameters on product yields and character. Fuel Proces. Technol. 129: 24-38. DOI: 10.1016/j.fuproc.2014.08.014.

Azeez A.M., Meier D., Odermatt J., Willner T. (2010) Fast pyrolysis of African and European lignocellulosic biomasses using $P y-G C / M S$ and fluidized bed reactor. Energy Fuels 24(3): 2078-2085. DOI: 10.1021/ef9012856.

Baglioni P., Chiaramonti D., Bonini M., Soldaini I., Tondi G. (2001) Bio crude oil/diesel oil emulsification: main achievements of the emulsification process and preliminary results of tests on diesel engine. Progr. Thermochem. Biomass Conver. 1525-1539. DOI: 10.1002/9780470694954.ch126.

Baloch H.A., Nizamuddin S., Siddiqui M.T.H., Riaz S., Jatoi A.S., Dumbre D.K., Mubarak N.M., Srinivasan M.P., Griffin G.J. (2018) Recent advances in production and upgrading of bio-oil from biomass: a critical overview. J. Environ. Chem. Eng. 6(4): 5101-5118. DOI: org/10.1016/j.jece. 2018.07.050

Beneroso D., Monti T., Kostas E.T., Robinson J. (2017) Microwave pyrolysis of biomass for bio-oil production: scalable processing concepts. Chem. Eng. J. DOI: 10.1016/j.cej. 2017.01.130.

Bermúdez J.M., Beneroso D., Rey-Raap N., Arenillas A., Menéndez J.A. (2015) Energy consumption estimation in the scaling-up of microwave heating processes. Chem. Eng. Proces. Process Intensif. 95: 1-8. DOI: 10.1016/j.cep. 2015.05.001.

Bertero M., Gorostegui H.A., Orrabalis C.J., Guzmán C.A., Calandri E.L., Sedran U. (2014) Characterization of the liquid products in the pyrolysis of residual chanar and palm fruit biomasses. Fuel 116: 409-414. DOI: 10.1016/j.fuel. 2013.08.027.

Bilbao J., Olazar M., Lopez G., Amutio M., Alvarez J. (2018) Bio-oil production. [in:] Bioenergy and biofuels. CRC Press: 209-238.

Biller P., Ross A.B. (2011) Potential yields and properties of oil from the hydrothermal liquefaction of microalgae with different biochemical content. Bioresour. Tech. 102(1): 215-225. DOI: 10.1016/j.biortech.2010.06.028.

Boocock D.G.B., Konar S.K., Glaser G. (2001) The formation of petrodiesel by the pyrolysis of fatty acid methyl esters over activated alumina. Progr. Thermochem. Biomass Conver. 1517-1524. DOI: 10.1002/9780470694954.ch125.

Bridgwater A.V. (2003) Renewable fuels and chemicals by thermal processing of biomass. Chem. Eng. J. 91(2): 87-102. DOI: 10.1016/S1385-8947(02)00142-0.
Bridgwater A.V. (2019) Pyrolysis of solid biomass: basics, processes and products. Energy from organic materials (biomass). [in:] Encyclopedia of sustainability science and technology. 1221-1250.

Bridgwater A.V., Meier D., Radlein D. (1999) An overview of fast pyrolysis of biomass. Organic Geochem. 30(12): 1479-1493. DOI: 10.1016/S0146-6380(99)00120-5.

Bulushev D.A., Ross J.R. (2011) Catalysis for conversion of biomass to fuels via pyrolysis and gasification: a review. Catalysis Today 171(1): 1-13.

Cao Q., Xie K.C., Bao W.R., Shen S.G. (2004) Pyrolytic behavior of waste corn cob. Bioresource Technol. 94(1): 83-89. DOI: 10.1016/j.biortech.2003.10.031.

Chen T., Wu C., Liu R., Fei W., Liu S. (2011) Effect of hot vapor filtration on the characterization of bio-oil from rice husks with fast pyrolysis in a fluidized-bed reactor. Bioresource Technol. 102(10): 6178-6185. DOI: 10.1016/ j.biortech.2011.02.023.

Chinnappan A., Baskar C., Kim H. (2016) Biomass into chemicals: green chemical conversion of carbohydrates into 5-hydroxymethylfurfural in ionic liquids. RSC Adv. 6(68): 63991-64002.

David E., Kopac J. (2018) Pyrolysis of rapeseed oil cake in a fixed bed reactor to produce bio-oil. J. Anal. Appl. Pyrolys. 134: 495-502.

Demirbaş A. (2001) Relationships between lignin contents and heating values of biomass. Energy Conver. Mgmt 42(2): 183-188. DOI: 10.1016/S0196-8904(00)00050-9.

Dickerson T., Soria J. (2013) Catalytic fast pyrolysis: a review. Energies 6(1): 514-538. DOI: 10.3390/en6010514.

Dote Y., Sawayama S., Inoue S., Minowa T., Yokoyama S.Y. (1994) Recovery ofliquid fuel from hydrocarbon-rich microalgae by thermochemical liquefaction. Fuel 73(12): 1855-1857. DOI: 10.1016/0016-2361(94)90211-9.

Duan P.G., Yang S.K., Xu Y.P., Wang F., Zhao D., Weng Y.J., Shi X.L. (2018) Integration of hydrothermal liquefaction and supercritical water gasification for improvement of energy recovery from algal biomass. Energy 155: 734-745.

Duan P., Savage P.E. (2011) Upgrading of crude algal bio-oil in supercritical water. Bioresource Technol. 102(2): 1899-1906. DOI: 10.1016/j.biortech.2010.08.013.

Elliott D.C., Hart T.R., Schmidt A.J., Neuenschwander G.G., Rotness L.J., Olarte M.V., Zacher A.H., Albrecht K.O., Hallen R.T., Holladay J.E. (2013) Process development for hydrothermal liquefaction of algae feedstocks in a continuous-flow reactor. Algal Res. 2(4): 445-454. DOI: 10.1016/ j.algal.2013.08.005.

Gabrielle B., Bamičre L., Caldes N., De Cara S., Decocq G., Ferchaud F., Loyce C., Pelzer E., Perez Y., Wohlfahrt J., Richard G. (2014) Paving the way for sustainable bioenergy in Europe: technological options and research avenues for largescale biomass feedstock supply. Renew. Sustain. Energy Rev. 33: 11-25. DOI: 10.1016/j.rser. 2014.01.050.

Gomez C., Velo E., Barontini F., Cozzani V. (2009) Influence of secondary reactions on the heat of pyrolysis of biomass. 
Ind. Eng. Chem. Res. 48(23): 10222-10233. DOI: 10.1021/ ie9007985.

Gong F., Yang Z., Hong C., Huang W., Ning S., Zhang Z., Xu Y., Li Q. (2011) Selective conversion of bio-oil to light olefins: controlling catalytic cracking for maximum olefins. Bioresour. Technol. 102(19): 9247-9254. DOI: 10.1016/ j.biortech.2011.07.009.

Grierson S., Strezov V., Ellem G., Mcgregor R., Herbertson J. (2009) Thermal characterisation of microalgae under slow pyrolysis conditions. J. Analyt. Appl. Pyrolys. 85(1): 118-123. DOI: 10.1016/j.jaap.2008.10.003.

Guedes R.E., Luna A.S., Torres A.R. (2017) Operating parameters for bio-oil production in biomass pyrolysis: a review. J. Analyt. Appl. Pyrol.

Guizani C., Louisnard O., Sanz F.E., Salvador S., Hermany D. (2014) Pyro-gasification of thin wood-chips in pure $\mathrm{CO}_{2}$ experiments and modelling. [in:] $5^{\text {th }}$ International Renewable Energy Congress (IREC), 2014. IEEE: 1-6.

He C., Tang C., Li C., Yuan J., Tran K.Q., Bach Q.V., Qiu R., Yang Y. (2018) Wet torrefaction of biomass for high quality solid fuel production: a review. Renew. Sustain. Energy Rev. 91: 259-271.

Hilten R.N., Bibens B.P., Kastner J.R., Das K.C. (2009) In-line esterification of pyrolysis vapor with ethanol improves biooil quality. Energy Fuels 24(1): 673-682. DOI: 10.1021/ ef900838g.

Isa Y.M., Ganda E.T. (2018) Bio-oil as a potential source of petroleum range fuels. Renew. Sustain. Energy Rev. 81: $69-75$.

Islam M.N., Beg M.R.A., Islam M.R. (2005) Pyrolytic oil from fixed bed pyrolysis of municipal solid waste and its characterization. Renew. Energy 30(3): 413-420. DOI: 10.1016/ j.renene.2004.05.002.

Jand N., Foscolo P.U. (2005) Decomposition of wood particles in fluidized beds. Ind. Eng. Chem. Res. 44(14): 5079-5089. DOI: $10.1021 / \mathrm{ie} 040170$ a.

Kabir G., Hameed B.H. (2017) Recent progress on catalytic pyrolysis of lignocellulosic biomass to high-grade bio-oil and bio-chemicals. Renew. Sustain. Energy Rev. 70: 945-967.

Kan T., Strezov V., Evans T.J. (2016) Lignocellulosic biomass pyrolysis: A review of product properties and effects of pyrolysis parameters. Renew. Sustain. Energy Rev. 57: 1126-1140. DOI: 10.1016/j.rser.2015.12.185

Karaosmanoğlu F., Tetik E., Göllü E. (1999) Biofuel production using slow pyrolysis of the straw and stalk of the rapeseed plant. Fuel Proces. Tech. 59(1): 1-12. DOI: 10.1016/S0378-3820(99)00004-1.

Kumar A.K., Sharma S. (2017) Recent updates on different methods of pretreatment of lignocellulosic feedstocks. a review. Bioresour. Bioproces. 4(1): 7.

Li D., Chen L., Zhang X., Ye N., Xing F. (2011) Pyrolytic characteristics and kinetic studies of three kinds of red algae. Biomass Bioenergy 35(5): 1765-1772. DOI: 10.1016/ j.biombioe.2011.01.011

Li J., Yan R., Xiao B., Wang X., Yang H. (2007) Influence of temperature on the formation of oil from pyrolyzing palm oil wastes in a fixed bed reactor. Energy Fuels 21(4): 2398-2407. DOI: 10.1021/ef060548c

Lu Q., Yang X.L., Zhu X.F. (2008) Analysis on chemical and physical properties of bio-oil pyrolyzed from rice husk. J. Anal. Appl. Pyrolysis 82(2): 191-198. DOI: 10.1016/j.jaap. 2008.03.003.

Ly H.V., Kim S.S., Woo H.C., Choi J.H., Suh D.J., Kim J. (2015) Fast pyrolysis of macroalga Saccharina japonica in a bubbling fluidized-bed reactor for bio-oil production. Energy 93: 1436-1446.

Ly H.V., Lim D.H., Sim J.W., Kim S.S., Kim J. (2018) Catalytic pyrolysis of tulip tree (Liriodendron) in bubbling fluidizedbed reactor for upgrading bio-oil using dolomite catalyst. Energy 162: 564-575.

Ma W., Liu B., Zhang R., Gu T., Ji X., Zhong L., Chen G., Ma L., Cheng Z., Li X. (2018) Co-upgrading of raw bio-oil with kitchen waste oil through fluid catalytic cracking (FCC). Appl. Energy 217: 233-240.

Mahinpey N., Murugan P., Mani T., Raina R. (2009) Analysis of bio-oil, biogas, and biochar from pressurized pyrolysis of wheat straw using a tubular reactor. Energy Fuels 23(5): 2736-2742.

Mamaeva A., Tahmasebi A., Tian L., Yu J. (2016) Microwaveassisted catalytic pyrolysis of lignocellulosic biomass for production of phenolic-rich bio-oil. Bioresour. Tech. 211: 382-389. DOI: 10.1016/j.biortech.2016.03.120.

Miao X., Wu Q., Yang C. (2004) Fast pyrolysis of microalgae to produce renewable fuels. J. Anal. Appl. Pyrolysis 71(2): 855-863. DOI: 10.1016/j.jaap.2003.11.004.

Miranda R., Bustos-Martinez D., Blanco C.S., Villarreal M.G., Cantú M.R. (2009) Pyrolysis of sweet orange (Citrus sinensis) dry peel. J. Anal. Appl. Pyrolysis 86(2): 245-251. DOI: 10.1016/j.jaap.2009.06.001.

Mohamed A.R., Hamzah Z., Daud M.Z.M., Zakaria Z. (2013) The effects of holding time and the sweeping nitrogen gas flowrates on the pyrolysis of EFB using a fixed - bed reactor. Proc. Eng. 53: 185-191. DOI: 10.1016/j.proeng. 2013.02.024.

Mohan D., Pittman C.U., Steele P.H. (2006) Pyrolysis of wood/biomass for bio-oil: a critical review. Energy Fuels 20(3): 848-889. DOI: 10.1021/ef0502397.

Montazeri N., Oliveira A.C., Himelbloom B.H., Leigh M.B., Crapo C.A. (2013) Chemical characterization of commercial liquid smoke products. Food Sci. Nutr. 1(1): 102-115.

Morgan Jr. H.M., Bu Q., Liang J., Liu Y., Mao H., Shi A., Lei H., Ruan R. (2017) A review of catalytic microwave pyrolysis of lignocellulosic biomass for value-added fuel and chemicals. Bioresour. Tech. 230: 112-121. DOI: 10.1016/ j.biortech.2017.01.059.

Mostafazadeh A.K., Solomatnikova O., Drogui P., Tyagi R.D. (2018) A review of recent research and developments in fast pyrolysis and bio-oil upgrading. Biomass Conver. Biorefin. 1-35.

Neves D., Thunman H., Matos A., Tarelho L., Gómez-Barea A. (2011) Characterization and prediction of biomass pyrolysis products. Progr. Energy Combustion Sci. 37(5): 611-630. DOI: 10.1016/j.pecs.2011.01.001. 
Norouzi O., Jafarian S., Safari F., Tavasoli A., Nejati B. (2016) Promotion of hydrogen-rich gas and phenolic-rich bio-oil production from green macroalgae Cladophora glomerata via pyrolysis over its bio-char. Bioresour. Tech. 219: 643-651. DOI: 10.1016/j.biortech.2016.08.017.

Önal E.P., Uzun B.B., Pütün A.E. (2011) Steam pyrolysis of an industrial waste for bio-oil production. Fuel Proces. Tech. 92(5): 879-885. DOI: 10.1016/j.fuproc.2010.12.006.

Özbay N., Pütün A.E., Uzun B.B., Pütün E. (2001) Biocrude from biomass: pyrolysis of cottonseed cake. Renew. Energy 24(3): 615-625. DOI: 10.1016/S0960-1481(01) 00048-9.

Park H.J., Dong J.I., Jeon J.K., Park Y.K., Yoo K.S., Kim S.S., Kim J., Kim S. (2008) Effects of the operating parameters on the production of bio-oil in the fast pyrolysis of Japanese larch. Chem. Eng. J. 143(1): 124-132. DOI: 10.1016/ j.cej.2007.12.031.

Park J., Lee Y., Ryu C., Park Y.K. (2014) Slow pyrolysis of rice straw: Analysis of products properties, carbon and energy yields. Bioresour. Tech. 155: 63-70. DOI: 10.1016/ j.biortech.2013.12.084.

Paysepar H., Rao K.T.V., Yuan Z., Nazari L., Shui H., Xu C.C. (2018) Zeolite catalysts screening for production of phenolic bio-oils with high contents of monomeric aromatics/phenolics from hydrolysis lignin via catalytic fast pyrolysis. Fuel Proces. Tech. 178: 362-370.

Pütün A.E., Özbay N., Önal E.P., Pütün E. (2005) Fixed-bed pyrolysis of cotton stalk for liquid and solid products. Fuel Proces. Tech. 86(11): 1207-1219. DOI: 10.1016/j.fuproc. 2004.12.006.

Pütün E., Ateș F., Pütün A.E. (2008) Catalytic pyrolysis of biomass in inert and steam atmospheres. Fuel 87(6): 815-824. DOI: 0.1016/j.fuel.2007.05.042.

Quispe I., Navia R., Kahhat R. (2017) Energy potential from rice husk through direct combustion and fast pyrolysis: a review. Waste Manage. 59: 200-210. DOI: 10.1016/ j.wasman.2016.10.001.

Ranzi E., Corbetta M., Manenti F., Pierucci S. (2014) Kinetic modeling of the thermal degradation and combustion of biomass. Chem. Eng. Sci. 110: 2-12.

Reddy H.K., Muppaneni T., Patil P.D., Ponnusamy S., Cooke P., Schaub T., Deng S. (2014) Direct conversion of wet algae to crude biodiesel under supercritical ethanol conditions. Fuel 115: 720-726. DOI: 10.1016/j.fuel.2013.07. 090.

Ren Q., Zhao C., Wu X., Liang C., Chen X., Shen J., Tang G., Wang Z. (2009) Effect of mineral matter on the formation of NOx precursors during biomass pyrolysis. J. Anal. Appl. Pyrolysis 85(1): 447-453. DOI: 10.1016/j.jaap. 2008. 08. 006.

Resende F.L., Savage P.E. (2010) Kinetic model for noncatalytic supercritical water gasification of cellulose and lignin. AIChE J. 56(9): 2412-2420. DOI: 10.1002/aic.12165.

Reyhanitash E. (2013) Upgrading pyrolysis oil to produce liquid transportation fuels. Doctoral dissertation, The University of Western Ontario.
Ronsse F., Dickinson D., Nachenius R., Prins W. (2013) Biomass pyrolysis and biochar characterization. [in:] Proceedings of the $1^{\text {st }}$ FOREBIOM Workshop 4(4): 2013.

Ross A.B., Biller P., Kubacki M.L., Li H., Lea-Langton A., Jones J.M. (2010) Hydrothermal processing of microalgae using alkali and organic acids. Fuel 89(9): 2234-2243. DOI: $10.1016 /$ j.fuel.2010.01.025.

Safi M.J., Mishra I.M., Prasad B. (2004) Global degradation kinetics of pine needles in air. Thermochim. Acta 412(1): 155-162. DOI: 10.1016/j.tca.2003.09.017.

Salehi E., Abedi J., Harding T. (2009) Bio-oil from sawdust: pyrolysis of sawdust in a fixed-bed system. Energy Fuels 23(7): 3767-3772. DOI: 10.1021/ef900112b.

Scott D.S., Majerski P., Piskorz J., Radlein D. (1999) A second look at fast pyrolysis of biomass - the RTI process. J. Analyt. Appl. Pyrol. 51(1): 23-37. DOI: 10.1016/S01652370(99)00006-6.

Shi W., Li S., Jia J., Zhao Y. (2013) Highly efficient conversion of cellulose to bio-oil in hot-compressed water with ultrasonic pretreatment. Industr. Eng. Chem. Res. 52(2): 586-593. DOI: 10.1021/ie3024966.

Shihadeh A., Hochgreb S. (2002) Impact of biomass pyrolysis oil process conditions on ignition delay in compression ignition engines. Energy Fuels 16(3): 552-561. DOI: 10.1021/ef010094d.

Singh R., Krishna B.B., Mishra G., Kumar J., Bhaskar T. (2016) Strategies for selection of thermo-chemical processes for the valorisation of biomass. Renew. Energy 98: 226-237. DOI: 10.1016/j.renene.2016.03.023.

Tekin K., Karagöz S., Bektaş S. (2014) A review of hydrothermal biomass processing. Renew. Sustain. Energy Rev. 40: 673-687. DOI: 10.3390/en5093295.

Wang F., Tian Y., Zhang C.C., Xu Y.P., Duan P.G. (2018a) Hydrotreatment of bio-oil distillates produced from pyrolysis and hydrothermal liquefaction of duckweed: a comparison study. Sci. Total Environ. 636: 953-962.

Wang J., Zhong Z., Ding K., Deng A., Hao N., Meng X., Ben H., Ruan R., Ragauskas A.J. (2018b) Catalytic fast pyrolysis of bamboo sawdust via a two-step bench scale bubbling fluidized bed/fixed bed reactor: Study on synergistic effect of alkali metal oxides and HZSM-5. Energy Conv. Management 176: 287-298.

Wang X., Wu J., Chen Y., Pattiya A., Yang H., Chen H. (2018c) Comparative study of wet and dry torrefaction of corn stalk and the effect on biomass pyrolysis polygeneration. Bioresour. Tech. 258: 88-97.

Xiong W.M., Zhu M.Z., Deng L., Fu Y., Guo Q.X. (2009) Esterification of organic acid in bio-oil using acidic ionic liquid catalysts. Energy Fuels 23(4): 2278-2283. DOI: 10.1016/j.apenergy.2009.06.025.

Xu X., Tu R., Sun Y., Li Z., Jiang E. (2018) Influence of biomass pretreatment on upgrading of bio-oil: Comparison of dry and hydrothermal torrefaction. Bioresour. Tech. 262: 261-270.

Xu Y., Zheng X., Yu H., Hu X. (2014) Hydrothermal liquefaction of Chlorella pyrenoidosa for bio-oil production over Ce/HZSM-5. Bioresour. Tech. 156: 1-5. 
Yaman E., Yargic A.S., Ozbay N., Uzun B.B., Kalogiannis K.G., Stefanidis S.D., Pachatouridou E.P., Iliopoulou E.F., Lappas A.A. (2018) Catalytic upgrading of pyrolysis vapours: Effect of catalyst support and metal type on phenolic content of bio-oil. J. Cleaner Prod. 185: 52-61.

Yang Y., Gilbert A., Xu C. (2009) Production of bio crude from forestry waste by hydro liquefaction in sub/super critical methanol. AIChE J. 55(3): 807-819.

Yanik J., Kornmayer C., Saglam M., Yüksel M. (2007) Fast pyrolysis of agricultural wastes: Characterization of pyrolysis products. Fuel Proces. Tech. 88(10): 942-947. DOI: 10.1002/aic.11701.

Yin S., Tan Z. (2012) Hydrothermal liquefaction of cellulose to bio-oil under acidic, neutral and alkaline conditions. Appl. Energy 92: 234-239.

Yu G., Zhang Y., Schideman L., Funk T.L., Wang Z. (2009) Hydrothermal liquefaction of low lipid content microalgae into bio-crude oil. Trans. ASABE 54(1): 239-246. DOI: 10.1016/j.apcatb.2013.03.010.
Zabaniotou A.A., Roussos A.I., Koroneos C.J. (2000) A laboratory study of cotton gin waste pyrolysis. J. Anal. Appl. Pyrolysis 56(1): 47-59. DOI: 10.13031/2013.36241.

Zhang Q., Chang J., Wang T., Xu Y. (2007) Review of biomass pyrolysis oil properties and upgrading research. Energy Conv. Management 48(1): 87-92. DOI: 10.1016/j.fuel. 2016.03.103.

Zhang S., Chen T., Xiong Y., Dong Q. (2017) Effects of wet torrefaction on the physicochemical properties and pyrolysis product properties of rice husk. Energy Conv. Management 141: 403-409.

Zheng J.L., Zhu Y.H., Zhu M.Q., Wu H.T., Sun R.C. (2018) Biooil gasification using air-Steam as gasifying agents in an entrained flow gasifier. Energy 142: 426-435.

Zhou C.H., Xia X., Lin C. X., Tong D.S., Beltramini J. (2011) Catalytic conversion of lignocellulosic biomass to fine chemicals and fuels. Chem. Soc. Rev. 40(11): 5588-5617. DOI: 10.1016/j.enconman.2007.11.005. 